\title{
Multilevel Analysis on the Determinants of Overweight and Obesity among Primary School Students in Boyolali, Central Java
}

\author{
Dwi Wijayanti'), Harsono Salimo²), Yulia Lanti Retno Dewi3) \\ 1)Masters Program on Public Health, Universitas Sebelas Maret \\ ${ }^{2)}$ Department of Pediatrics, Dr. Moewardi Hospital/ \\ Faculty of Medicine, Universitas Sebelas Maret \\ 3)Faculty of Medicine, Universitas Sebelas Maret
}

\begin{abstract}
Background:Fat and obesity are serious problems in children because they will continue into adulthood. Diarrhea occurs in groups of children under five years old (toddlers). According to the 2013 risk assessment, in Boyolali District the prevalence of obesity in children was $11.6 \%$ consisted of $7.5 \%$ fat and $4.1 \%$ obese. This study aimed to examine determinants of overweight and obesity among primary school students in Boyolali, Central Java.

Subjects and Method: This was an analytic observational study with a case-control design. The study was conducted at 25 elementary schools in Ngemplak sub-district, Boyolali, Central Java, from April 2017 to June 2018. A sample of 200 students was selected by fixed disease sampling. The dependent variable was fat and obese nutritional status. Independent variables were family income, pocket money, paternal BMI, maternal BMI, nutritional intake, and physical activity. The data were collected by questionnaire and analyzed by a multilevel linear regression.

Results: Family income $(b=1.65 ; 95 \% \mathrm{CI}=8.28$ to $2.48 ; \mathrm{p}<0.001)$, pocket money $(\mathrm{b}=0.001 ; 95 \%$ CI 0.01 to $0.01 ; \mathrm{p}<0.001)$, paternal BMI $(\mathrm{b}=0.11 ; 95 \% \mathrm{CI}=0.06$ to $0.16 ; \mathrm{p}<0.001)$, maternal $\mathrm{BMI}$ $(b=0.06 ; 95 \% \mathrm{CI}=0.38$ to $0.96 ; \mathrm{p}<0.001)$, nutritional intake $(\mathrm{b}=0.87 ; 95 \% \mathrm{CI}=0.35$ to1.14; $\mathrm{p}=$ 0.001), and physical activity $(\mathrm{b}=-0.04 ; 95 \% \mathrm{CI}=-0.05$ to $-0.06 ; \mathrm{p}<0.001)$ increased fat and obesity in children. School had a strong contextual effect on fat and obesity among children with ICC $=$ $14.34 \%$.

Conclusion: Family income, pocket money, paternal BMI, maternal BMI, nutritional intake, and physical activity increase fat and obesity in children. School has a strong contextual effect on fat and obesity among children.
\end{abstract}

Keywords: determinants, fat, obesity, physical activity, nutritional intake, multilevel analysis

\section{Correspondence:}

Dwi Wijayanti. Masters Program in Public Health, Universitas Sebelas Maret. Jl. Ir. Sutami No. 36A, Surakarta 57126, Central Java. Email: dwijaymail@gmail.com. Mobile:+6285642214066.

\section{BACKGROUND}

Overweight and obesity are abnormal conditions that are characterized by an increase in excessive body fat, generally accumulated around the subcutaneous tissue, around the organs and sometimes filtered into organs that can disrupt health (WHO, 2014; Rehani et al., 2017). Fat and obesity are serious problems in children because they will continue into adulthood (Tovey, 2017).
The further impact is an increased risk of premature death. It is estimated that one in 10 premature deaths among Canadian adults aged 20 to 64 years is directly related to obesity. Obesity can cause serious chronic conditions that reduce overall quality of life (WHO, 2012; Rehani et al., 2017; Tovey, 2017).

Children are vulnerable to nutritional problems because the acceleration of body growth and development requires more energy. Changes in lifestyle and eating ha- 
bits require adjustments to input of energy and nutrients (Taha and Marawan, 2015). Overweight and obesity in childhood have serious long-term consequences for children's health. Obesity is a troubling problem, because it can reduce a person's confidence and cause psychological disorders and possible discrimination from the surrounding environment (Umairah, 2012; Yamborisut, 2017).

In this study, Studyers wanted to know the individual determinants and school environment (multilevel analysis) of obesity and obesity in elementary school students in Boyolali District.

\section{SUBJECTS AND METHOD}

\section{Study Design}

This was an observational analytic study with a case control design conducted in the City of Boyolali, Central Java, Indonesia in April 2017 to June 2018.

\section{Population and Samples}

The populations in this study were elementary school students in the Ngemplak District area, Boyolali Regency. A sample of 200 students was selected by fixed disease sampling, consisting of 100 overweight/ obese children and 100 normal weight children.

\section{Study Variables}

The dependent variable was fat and obese nutritional status. The independent variables at level 1 were family income, pocket money, paternal BMI, maternal BMI, nutritional intake, and physical activity. School was independent variable at level 2.

\section{Operational Definition of Variables}

Overweight was defined as a nutritional status expressed by body mass index per age. The measurement scale was continous, but it was transformed into dichotomous, coded o for normal weight ( $<1 \mathrm{SD})$ and 1 for overweigth/obese ( $>1 \mathrm{SD}$ ).
Mother's BMI is the mother's body condition which is calculated from the ratio between body weight $(\mathrm{Kg})$ and height $(\mathrm{m})$. Father's BMI is the mother's body condition which is calculated from the ratio between body weight $(\mathrm{Kg})$ and height $(\mathrm{m})$. The measurement scale was continous, but it was transformed into dichotomous, coded o for o for normal (BMI <23) and 1 for overweight (BMI > 23).

Parental income was the total income of all family members in one month as a reward for working. The measurement scale was continous, but it was transformed into dichotomous, coded o for low income $(<\mathrm{Rp}$ $1,652,000)$ and high income ( $>\mathrm{Rp}$ $1,652,000)$.

Food intake was all types of food and drink consumed by the body in the form of energy based on the results of a 24-hour food recall. The measurement scale was continous, but it was transformed into dichotomous, coded o for low ( $<80 \%$ NAR), and 1 for high ( $\geq 80 \%$ NAR).

Pocket money was money given by parents to spend at any time, averaged from the last 1 week. The measurement scale was continous, but it was transformed into dichotomous, coded o for low ( $<$ mean) and 1 for high ( $\geq$ mean).

Physical activity was any body movement that increases energy expenditure and energy burning for the last 7 days before the interview. The measurement scale was continous, but it was transformed into dichotomous, coded o for low (score <78) and high (score $\geq 78$ ).

Snacks in the school environment were foods that are found in the school environment and routinely consumed by most school children. School snacks were assessed based on the number of school snacks and types of school snacks. The measurement scale was continous. 


\section{Study Instruments}

Data on the nutritional status of students, BMI of mothers and fathers were obtained from direct measurements using tread and microtoise scales. Data related to family income, pocket money, nutritional intake and physical activity were obtained using questionnaires. Snack data in the school environment were obtained using the observation sheet.

\section{Data Analysis}

Univariate analysis was performed to see the frequency distribution and the percentage of the characteristics of the Study subjects. Bivariate analysis was conducted to study the relationship between obesity and obesity with independent variables using the chi-square test and calculation of odds ratios (OR) with a confidence level (CI) of 95\%. Furthermore, multivariate analysis was performed using linear regression through a multilevel approach.

\section{Ethical Clearance}

The Study ethics in this study included informed consent, anonymity, confidentiality and ethical clearance. The ethical clearance in this study was carried out at Dr. Moewardi Surakarta, number: 505 / IV / HREC / 2018.

\section{RESULTS}

\section{Univariat Analysis}

Table 1 shows that children from income families <UMR were 70 (35\%) and > UMR were 128 (65\%). Children with pocket money is < an average of 111 (55.5\%) and the average of 89 (45.5\%). Children who have fathers with a body mass index $<23$ are 92 (46\%) and $\geq 23$ are 108 (54\%). Children who have mothers with a body mass index $<23$ are 110 (55\%) and $\geq 23$ are 90 (45\%). Children with nutritional intake $<$ AKG consist of 123 (61.5\%) and $\geq$ NAR amount to $77(38.5 \%)$. Children with high physical activity were 109 (54.5\%) and low as many as 91 (45.5\%).

\section{Bivariate Analysis}

Table 2 shows the relationship of the independent variables (Amount of family income, pocket money, father's BMI, maternal BMI, nutritional intake and physical activity) with the dependent variable (fat and obese). The results of the full bivariate analysis can be seen in table 2.

Table 1. Univariate Analysis

\begin{tabular}{|c|c|c|}
\hline Variable & $\mathbf{n}$ & $\%$ \\
\hline \multicolumn{3}{|l|}{ Family Income } \\
\hline$<$ minimum wage & 70 & 35 \\
\hline >minimum wage & 128 & 65 \\
\hline \multicolumn{3}{|l|}{ Pocket money } \\
\hline$<$ average & 111 & 55.5 \\
\hline$\geq$ average & 89 & 44.5 \\
\hline \multicolumn{3}{|c|}{ Father's Nutritional } \\
\hline \multicolumn{3}{|c|}{ Status } \\
\hline$<23$ & 92 & 46 \\
\hline$\geq 23$ & 108 & 54 \\
\hline \multicolumn{3}{|c|}{ Maternal Nutritional } \\
\hline \multicolumn{3}{|c|}{ Status } \\
\hline$<23$ & 110 & 55 \\
\hline$\geq 23$ & 90 & 45 \\
\hline \multicolumn{3}{|l|}{ Nutritional Intake } \\
\hline$<$ NAR & 123 & 61.5 \\
\hline$\geq \mathrm{NAR}$ & 77 & 38.5 \\
\hline \multicolumn{3}{|l|}{ Physical Activity } \\
\hline High & 109 & 54.5 \\
\hline Low & 91 & 45.5 \\
\hline
\end{tabular}

\section{Multilevel Anaysis}

Multivariate analysis explained the effect of more than one independent variable on one dependent variable. The method used was multilevel linear regression by using the STATA 13 program.

Table 3 showed that family income $>$ minimum wage $(\mathrm{b}=1.65 ; 95 \% \mathrm{CI}=8.28$ to 2.48; $\mathrm{p}<0.001)$. High pocket money $(\mathrm{b}=$ $<0.01 ; 95 \% \mathrm{CI}=0.01$ to $0.01 ; \mathrm{p}<0.001)$, fathers $\mathrm{BMI}>23(\mathrm{~b}=0.11 ; 95 \% \mathrm{CI}=$ o.6oto 0.16 ; $\mathrm{p}<0.001)$ and maternal BMI $>23(\mathrm{~b}=$ o.06; $95 \% \mathrm{CI}=0.03$ to $0.09 ; \mathrm{p}<0.001$ ), high nutritional intake $(\mathrm{b}=0.87 ; 95 \% \mathrm{CI}=0.35$ to 1.40; $\mathrm{p}<0.001)$ have an effect in increasing the risk of obesity, while high physical 
activity $(b=-0.04 ; 95 \% \mathrm{CI}=-0.05$ to -0.06 ; $\mathrm{p}<0.001)$ has an effect in decreasing the risk of obesity.

In the data analysis, the results of ICC $=14.34 \%$. The indicator showed that the variation in fat and obesity by $14.34 \%$ was determined by variables at the school level. This number was greater than the standard 8 to $10 \%$ role of thumb, so the contextual effect shown from multilevel analysis were very important to note. The table also showed $\mathrm{p}<0.001$. These mean that the multilevel model was statistically significant from the usual logistic regression model.

Table 2. Bivariate Analysis of Fat and Obesity Determinants

\begin{tabular}{|c|c|c|c|c|c|c|c|c|c|}
\hline \multirow{3}{*}{ Variables } & \multicolumn{4}{|c|}{ Fat and Obesity } & \multirow{2}{*}{\multicolumn{2}{|c|}{ Total }} & \multirow{3}{*}{$\mathbf{O R}$} & \multirow{3}{*}{ CI (95\%) } & \multirow{3}{*}{$\mathbf{p}$} \\
\hline & \multicolumn{2}{|c|}{ Normal } & \multicolumn{2}{|c|}{ Fat/Obese } & & & & & \\
\hline & $\mathbf{n}$ & $\%$ & $\mathbf{n}$ & $\%$ & $\mathbf{N}$ & $\%$ & & & \\
\hline \multicolumn{10}{|l|}{ Parental Income } \\
\hline$<\mathrm{MW}$ & 63 & 87.5 & 9 & 12.5 & 72 & 100 & \multirow[t]{2}{*}{17.2} & \multirow{2}{*}{7.7 to 38.7} & \multirow[b]{2}{*}{$<0.001$} \\
\hline$\geq \mathrm{MW}$ & 37 & 28.9 & 91 & 71.1 & 128 & 100 & & & \\
\hline \multicolumn{10}{|l|}{ Pocket Money } \\
\hline$<$ average & 91 & 82 & 20 & 18 & 111 & 100 & \multirow[t]{2}{*}{40.4} & \multirow[b]{2}{*}{17.4 to 93.8} & \multirow[b]{2}{*}{$<0.001$} \\
\hline$\geq$ average & 9 & 10.1 & 80 & 89.9 & 89 & 100 & & & \\
\hline \multicolumn{10}{|c|}{ Maternal } \\
\hline \multicolumn{10}{|c|}{ Nutritional Status } \\
\hline$<23$ & 93 & 84.5 & 17 & 15.45 & 110 & 100 & \multirow[t]{2}{*}{64.8} & \multirow{2}{*}{25.6 to 164.1} & \multirow{2}{*}{$<0.001$} \\
\hline$\geq 23$ & 7 & 7.8 & 83 & 92.2 & 90 & 100 & & & \\
\hline \multirow{2}{*}{\multicolumn{10}{|c|}{$\begin{array}{l}\text { Paternal } \\
\text { Nutritional Status }\end{array}$}} \\
\hline & & & & & & & & & \\
\hline$<23$ & 76 & 9.6 & 16 & 19.5 & 82 & 100 & \multirow[t]{2}{*}{16.6} & \multirow{2}{*}{8.2 to 33.6} & \multirow{2}{*}{$<0.001$} \\
\hline$\geq 23$ & 24 & 22.3 & 84 & 77.7 & 108 & 100 & & & \\
\hline \multicolumn{10}{|l|}{ Nutrition Intake } \\
\hline$<$ NAR & 91 & 73.9 & 9 & $7 \cdot 3$ & 123 & 100 & \multirow[t]{2}{*}{21.5} & \multirow[t]{2}{*}{9.6 to 47.9} & \multirow[t]{2}{*}{$<0.001$} \\
\hline$\geq$ NAR & 32 & 41.5 & 68 & 88.3 & 77 & 100 & & & \\
\hline \multicolumn{10}{|c|}{ Physical Activity } \\
\hline High & 87 & 79.8 & 22 & 20.2 & 109 & 100 & 23.7 & 11.2 to 50.2 & $<0.001$ \\
\hline Low & 13 & 14.3 & 78 & 85.71 & 91 & 100 & & & \\
\hline
\end{tabular}

Table 3. The result of multilevel linear regression of fat and obesity determinants

\begin{tabular}{lcccc}
\hline \multicolumn{1}{c}{ Fat and Obesity } & \multirow{2}{*}{ b } & \multicolumn{2}{c}{ CI 95\% } & \multirow{2}{*}{ p } \\
\cline { 3 - 4 } Fixed Effect & & Lower limit & Upper limit & \\
Parent's income & 1.65 & 8.28 & 2.48 & $<0.001$ \\
Pocket money & $<0.01$ & $<0.01$ & $<0.01$ & $<0.001$ \\
Maternal BMI & 0.06 & 0.03 & 0.09 & $<0.001$ \\
Fathers BMI & 0.11 & 0.06 & 0.16 & $<0.001$ \\
Nutritional intake & 0.87 & 0.35 & 1.40 & 0.001 \\
Physical activity & -0.04 & -0.05 & -0.06 & $<0.001$ \\
Random Effect & & & & \\
Nutritional intake & 0.02 & $<0.01$ & & $<0.001$ \\
n observation = 200 & & & & \\
Log likelihood =-144.12 & & & & \\
LR test vs. linear regression, $\mathrm{p}<0.001$ & & & \\
ICC = 14.34\% & & & \\
\hline
\end{tabular}




\section{DISCUSSION \\ 1. The effect of parental income on fat and obesity}

The results of the analysis showed that there was a relationship between parents' income and obesity which was statistically significant, with high income, parents can increase the risk of obesity in children.

The result of this study was in line with Parengkuan et al., (2013), high family income was a risk factor for obesity $55.9 \%$ of obese children come from high-income families and in the non-obese group only $25 \%$ of high-income families. Increased income lead to increased food purchasing power, increased provision of family food and increased food consumption. Purchasing power also played a role in increasing eating habits outside the house in the form of high-speed fast food (Sigmund, 2018). The level of income affected the level of consumption of the community. If the income was high, then tje consumption expenditure increased and vice versa if the income was low, the consumption expenditure would also low (Danil, 2013)

\section{The effect of pocket money on fat and obesity}

The results of the analysis showed that there was a relationship between pocket money and obesity which was statistically significant, with pocket money, parents can increase the risk of obesity in children.

The result of this study was in line with study done by Punitha (2018)which stated that there was a significant relationship between pocket money and obesity. Participants who received an allowance more than 6.o $€$ each day showed an increase in consumption of fast food and skip breakfast. Overall, lower pocket money were less likely to be obese, consume fruit per day and were more likely to consume breakfast and sweets, compared to average recipients of pocket money. According to
Punitha et al. (2014), pocket money has a statistically significant effect seen among children who were overweight and obese and normal weight $(\mathrm{p}<0.050)$

\section{The effect of maternal BMI on fat and obesity}

The results of the analysis showed that there was a relationship between mothers' BMI and obesity which was statistically significant. Children who have mothers with a BMI > 23 were more likely to experience fat and obesity.

The result of this study was in line with Nudhira et al., (2017) which showed that there was a positive and significant effect of maternal body mass index (BMI) on overweight and obese toddlers. Overweight/obesity mothers increase their risk of having offspring with overweight/obesity compared to mothers with normal weight. Children with obese parents have a risk of 10.25 times to be obese and 3.03 times to experience metabolic syndrome compared to offspring without obesity (Han et al., 2015). According to Sanchez et al., (2017) the maternal BMI had a positive effect on child BMI.

\section{The effect of fathers BMI on fat and obesity}

The results of the analysis showed that there was a relationship between fathers' BMI and obesity which was statistically significant. Children who have fathers with a BMI > 23 were more likely to experience fat and obesity.

The result of this study was in line with Widiyanto et al., (2018) BMI of fathers $>23$ increased obesity in adolescents by 3.1 times than fathers with normal nutritional status. According to Sanchez et al., (2017) paternal BMI had a positive effect on child BMI ( $b=0.23 ; p<0.001)$, fat mass index $(b=0.13 ; p=0.026)$, fat free index $(b=0.21$; $\mathrm{p}<0.001)$ and waist circumference $(b=0.17$; $\mathrm{p}=0.001)$. 


\section{The effect of nutritional intake on fat and obesity}

The results of the analysis showed that cues to act had a relationship with the use of a pap smear and it was statistically significant. The perception of cues to act on a pap smear made women motivated to carry out the examination. This was because information through friends, health personnel, counseling, printed and electronic media influenced the behavior of using a pap smear.

The result of this study was in line with Hesketh (2017), sendentary lifestlyle in boys and girls increasing with age, watching television more than 4 hours per day can increase the risk of obesity. Whereas according to the Sacheck et al., (2010) and Syahrul et al., (2018), having physical fitness can be beneficial for a healthier body composition. Increased fitness was associated with increased HDL and decreased triglycerides in women and decreased serum glucose in men.

\section{The effect of physical activity on fat and obesity}

The results of the analysis showed that physical activity has a negative relationship to obesity in children. Children with high physical activity reduce their risk of experiencing fat and obesity.

The result of this study was in line with Hesketh (2017), sendentary lifestlyle in boys and girls increasing with age, watching television more than 4 hours per day can increase the risk of obesity. Whereas according to Sacheck et al.,(2010), having physical fitness can be beneficial for a healthier body composition. Increased fitness was associated with increased HDL and decreased triglycerides in women and decreased serum glucose in men. According to Estevan et al. (2018) and Al-Nakeeb (2012), children with higher physical acti- vity participation were more likely to have a normal body weight.

The conclusions of this study were high family income, high pocket money, high maternal and paternal BMI, and high nutritional intake increase the risk of fat and obesity in children. High physical activity reduced the incidence of fat and obesity in children. Variations at school level showed a strong contextual effect on the incidence of fat and obesity.

\section{REFERENCES}

Al-Nakeeb Y, Lyons M, Collins P, Al-Nuaim A, Al-Hazzaa A, Michael, Duncan, Nevill A (2012). Obesity, physical activity and sedentary behavior amongst British and Saudi Youth: A CrossCultural Study. Nt. J. Environ. Res. Public Health2012, 9, 1490-1506; doi: 10. $3390 /$ ijerph9041490

Cadenas-Sanchez C, Henriksson P, Henriksson H, Delisle Nyström C, Pomeroy J, Ruiz JR, Ortega FB, Löf M (2017). Parental body mass index and its association with body composition, physical fitness and lifestyle factors in their 4-year-old children: results from the MINISTOP trial.Eur $\mathrm{J}$ Clin Nutr. 71(10):1200-1205. Doi: 10.1038/ ejcn.2017 .62 .

Choukem S, Kamdeu-Chedeu J, Leary S, Mboue-Djieka Y, Nebongo D, Akazong C, Mapoure YN, Hamilton S, Gautier J, Claude J(2017). Overweight and obesity in children aged $3^{-13}$ years in urban Cameroon: a crosssectional study of prevalence and association with socio-economic status. BMC Obesity 4:7. Doi: 10.1186/s40608-017-0146-4

Estevan I, García-Massó X, Molina García J, Barnett LM (2018).Identifying profiles of children at risk of being less physically active: an exploratory study 
using a self-organised map approach for motor competence.J Sports Sci. 25:1-9. Doi: 10.1080/0264041

Grammatikopoulou MG, Gkiouras K, Daskalou E, Apostolidou E, Theodoridis X, Stylianou C, Galli-Tsinopoulou A, et al., (2018). The Mediterranean diet and the buying power of adolescents in Greece. $J$ Pediatr Endocrinol Metab. 31(7):773-780. Doi: 10.1515/jpem-2018-0039.

Gustafson A, Jilcott Pitts S, McDonald J, Ford H, Connelly P, Gillespie R, Liu E, et al., (2017). Direct effects of the home, school, and consumer food environments on the association between food purchasing patterns and dietary intake among rural adolescents in Kentucky and North Carolina. International Journal of Environmental Study and Public Health. 14(10): E1255. doi: 10. 3390/ijerph14101255.

Husni HK, Indrijanti H (2014). Pengaruh komparasi social pada model kecantikan di televise terhadap body image remaja putri obesitas. Jurnal Psikologi Pendidikan dan Perkembangan, 3(3), 207-212.

Jalali-Farahani S, Amiri P, Abbasi B, Karimi M, Cheraghi L, Daneshpour MS, Azizi F (2017). Maternal characteristics and incidence of overweight/ obesity in children: A 13-year followup study in an Eastern Mediterranean Population. Matern Child Health J. 21(5):1211-1220. doi: 10.1007/s10995016-2222-7.

Jilcott SB, Wade S, McGuirt JT, Wu Q, Lazorick S, Moore JB (2011). The association between the food environment and weight status among Eastern North Carolina Youth. Public Health Nutr. 14, 1610-1617.
Hesketh R, Lakshman, Van S (2017). Barriers and facilitators to young children's physical activity and sedentary behaviour: A systematic review and synthesis ff qualitative literature. Obesity Reviews. 18, 987-1017, doi: 10. 1111/obr. 12562

Li M, Xue H, Jia P, Zhao Y, Wang Z, Xu F, Wang Y (2017). Pocket money, eating behaviors, and weight status among Chinese children: The childhood obesity study in China mega-cities. Prev Med. 100:208-215. Doi: 10.1016/j.ypmed.2017.04.031.

Mohammed S, Hanim AS, Amallina NM, Othman N, Nabeel W (2018). Factors predicting paediatric obesity among primary school children in Kuantan. International Journal of Care Scholars. 1(1).

Niswah SR, Soemanto RB, Murti B (2017). Factors associated with overweight and obesity in adolescents in Kartasura, Central Java. Journal of Health Promotion and Behavior. 2(3): 207217. https://doi.org/thejhpb.2016.02.03 .02

Nudhira U, Wekadigunawan SP, Murti B (2017). Path analysis on life course factors affecting overweight and obesity in children aged 2 to 5 years old in Surakarta. Journal of Epidemiology and Public Health (2017), 2(3): 267283. https://doi.org/10.26911/jepublichealth.2017.02.03.08

Parengkuan RR, Mayulu N, Ponidjan T (2013). Hubungan pendapatan keluarga dengan kejadian obesitas pada anak sekolah dasar di kota Manado. Jurnal Keperawatan, 1(1).

Punitha VC, Amudhan A, Sivaprakasam P, Rathnaprabhu V (2014). Pocket money: Influence on body mass index and dental caries among urban adolescents. Journal Clinic Diagnostic 
Research 8(12).doi: 10.7860/JCDR/2014/10498.5310

Rehani M (2017). Report Card on Access to Obesity Treatment for Adults in Canada.Canadian Obesity NetworkRéseau canadien en obésité. Edmonton, AB: Canadian Obesity Network Inc.

Sigmund E, Badura P, Sigmundová D, Voráčová J, Zacpal J, Kalman M, Pavelka J, et al., (2018). Trends and correlates of overweight/obesity in czech adolescents in relation to family socioeconomic status over a 12-year study period (2002-2014). BMC Public Health. 18(1):122. doi: 10. 1186/s12889-017-5013-1.

Syahrul S, Kimura R, Tsuda A, Susanto T, Saito R, Ahmad F (2016). Prevalence of underweight and overweight among school-aged children and it's association with children's sociodemographic and lifestyle in Indonesia. International Journal of Nursing Sciences. 3. 169e177

Taha AA, Marawan HM (2015). Socio-behavioral determinants of overweight and obesity in Egyptian Primary School children. Journal of Child \& Adolescent Behavior, 3: 236. Doi:10. 4172/2375-4494. 1000236
Tovey M (2017). Obesity and the public purse: weighing up the true cost to the taxpayer. The Institute of Economic Affairs Discussion Paper No. 80

Umairah SN, Yahya BT, Yusof SM (2012). Relationship between dietary pattern and body masss indext among primary school children. Asia J Clin Nutr, 4, 142-50

WHO (2014). Obesity and inequities: guidance for addressing inequities in overweight and obesity. WHO Library Cataloguing-in-Publication Data.

WHO (2017). Adolescent obesity and related behaviors: Trends and inequalities in the WHO European Region, 2002 to 2014. WHO Library CataloguingIn-Publication Data.

Widiyanto A, Murti B, Soemanto RB (2018). Multilevel analysis on the effects of socio-cultural, lifestyle factors, and school environment, on the risk of overweight in adolescents, Karanganyar District, Central Java. Journal of Epidemiology and Public Health, 3(1): 94-104. https://doi.org/10.26911/jepublichealth.2018.03.01. 08.

Yamborisut U, Mo-suwan L (2014). Prevalence of childhood and adolescent obesity in Thailand: A Review. J Med Assoc Thai; 97 (1): 44-51. 